ISSN 2236-0859

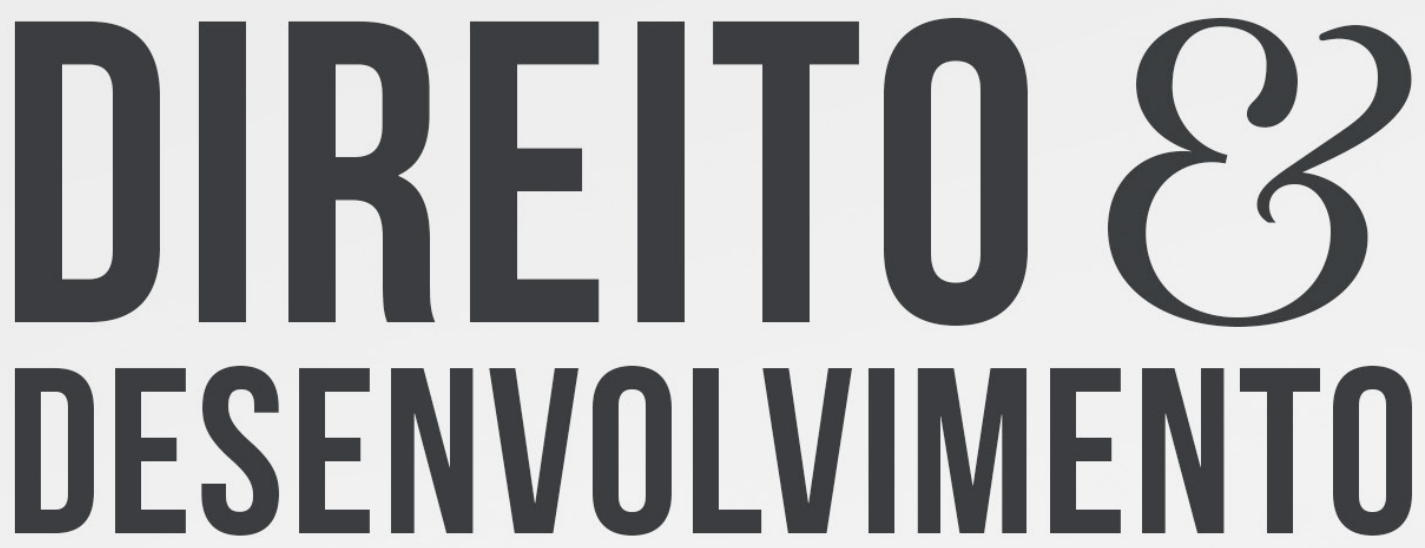

REVISTA DO PROGRAMA DE PÓS-GRADUAÇÃO EM DIREITO MESTRADO EM DIREITO E DESENVOLVIMENTO SUSTENTÁVEL

\title{
A COTA DE RESERVA AMBIENTAL NO SUPREMO \\ TRIBUNAL FEDERAL: REFLEXÕES SOBRE O INSTITUTO APÓS A DECLARAÇÃO DE CONSTITUCIONALIDADE
}

\author{
DÉLTON WINTER DE CARVALHO \\ LUCAS DE SOUZA LEHFELD \\ KELLY DE SOUZA BARBOSA
}




\title{
A COTA DE RESERVA AMBIENTAL NO SUPREMO TRIBUNAL FEDERAL: REFLEXÕES SOBRE O INSTITUTO APÓS A DECLARAÇÃO DE CONSTITUCIONALIDADE
}

\section{THE ENVIRONMENTAL RESERVE QUOTA IN THE SUPREME FEDERAL COURT: REFLECTIONS ON THE INSTITUTE AFTER CONSTITUTIONALITY STATEMENT}

Recebido: 28/09/2019

Aprovado: 04/11/2019
Délton Winter de Carvalho Lucas de Souza Lehfeld ${ }^{2}$ Kelly de Souza Barbosa ${ }^{3}$

\section{RESUMO:}

A Cota de Reserva Ambiental (CRA) visa cotizar o excedente legal de florestas e vegetações tuteladas juridicamente, para poder ser uma alternativa no procedimento de compensação ambiental para a regularização de propriedade rural. No entanto, a normatização desse instrumento no vigente Código Florestal possui críticas, que culminaram na apreciação pelo Supremo Tribunal Federal de forma (in)direta nas Ações Diretas de Inconstitucionalidade 4901, 4902, 4903 e 4937 e na Ação Declaratória de Constitucionalidade 42. Neste contexto, a CRA pode ser considerada um instrumento econômico e socioambiental promissor à proteção do meio ambiente saudável intergeracional, na atual configuração legislativa em que foi confirmada a sua constitucionalidade pelo Supremo Tribunal Federal? Com o objetivo precípuo de analisar as principais discussões atinentes à CRA nas ações diretas, o presente estudo traz como conclusão a necessidade de aprimoramento multidisciplinar ao instituto da CRA, para que realmente apresente resultados positivos à sociedade e ao meio ambiente ecológico.

Palavras-chave: Cota de Reserva Ambiental. Compensação. Regularização Ambiental. Constitucionalidade.

\begin{abstract}
:
The Environmental Reserve Quota (CRA) aims to quote the legal surplus of legally protected forests and vegetation, in order to be an alternative in the environmental compensation procedure for the regularization of rural property. However, the regulation of this instrument in the current Forest Code has criticisms, which culminated in the assessment by the Federal Supreme Court (in) direct form in the Direct Actions of Unconstitutionality 4901, 4902, 4903 and 4937 and

\footnotetext{
1 Doutor e Mestre em Direito pela Universidade do Vale do Rio dos Sinos. Pós-Doutor em Direito Ambiental e Direito dos Desastres pela University of California, Berkeley, CA, USA. Atualmente é Professor Adjunto I no Programa de Pós-Graduação em Direito PPGD da Universidade do Vale do Rio dos Sinos.. Email: delton@deltoncarvalho.com.br

2 Mestrado em Direito das Obrigações pela Universidade Estadual Paulista Júlio de Mesquita Filho (2001) e doutorado em Direito pela Pontifícia Universidade Católica de São Paulo (2006). Pós-Doutor em Direito pela Universidade de Coimbra (POR). Atualmente é docente titular da Universidade de Ribeirão Preto (Graduação e Pós-Graduação Stricto Sensu em Direito (mestrado) e Tecnologia Ambiental (mestrado e doutorado)), Coordenador do Curso de Direito do Centro Universitário Barão de Mauá (graduação e pósgraduação EAD) e docente do Centro Universitário da Fundação Educacional de Barretos. Email: lehfeldrp@gmail.com

3 Doutoranda em Direito pela Universidade do Vale do Rio dos Sinos - UNISINOS. Mestre em Direitos Coletivos e Cidadania pela Universidade de Ribeirão Preto - UNAERP. Email: kelly_sbarbosa@hotmail.com
} 
in the Declaratory Action of Constitutionality 42. In this context, the CRA can be considered a promising socio-environmental and economic instrument to protect the intergenerational healthy environment, in the current legislative configuration in which its constitutionality was confirmed by the Federal Supreme Court? With the main objective of analyzing the main discussions regarding the CRA in direct actions, the present study brings as conclusion the need for multidisciplinary upgrading to the CRA Institute, in order to truly present positive results to society and the ecological environment.

Keywords: Environmental Reserve Quota. Compensation. Environmental Regularization. Constitutionality.

\section{INTRODUÇÃO}

Com o intuito de aliar o mandamento constitucional para o meio ambiente ecologicamente equilibrado intergeracional com os pressupostos de sustentabilidade e desenvolvimento econômico sustentável, a Lei no 12.651/2012 (vulgo Código Florestal) (re) apresentou institutos e procedimentos atinentes ao direito ambiental. No entanto, várias de suas propostas, que estão relacionadas as áreas verdes especialmente tuteladas do país, causaram e causam discussões no âmbito jurídico, social, ambiental e político.

Tamanha a tensão jurídica e política em torno do Códex Florestal, que vários dispositivos foram levados a apreciação do Supremo Tribunal Federal, pelas Ações Diretas de Inconstitucionalidade 4901, 4902, 4903 e 4937 (todas propostas em 2013) e pela Ação Declaratória de Constitucionalidade 42 (proposta em 2016).

Dentre as atualizações propostas pelo legislador e questionadas nas ações diretas, está a matéria referente à Cota de Reserva Ambiental (CRA), disciplinada sobretudo nos artigos 13, $\S 1^{-0} ; 44 ; 48, \S 2^{-0} ; 66, \S \S 5^{\circ}$ e 6o do Código Florestal de 2012.

A Cota de Reserva Ambiental é um título representativo de áreas verdes especialmente tuteladas em percentuais de proteção acima do legalmente estipulado, que pode ser negociado em um Mercado de ativos florestais. Como instrumento econômico e socioambiental, a cota pode ser utilizada no processo de regularização ambiental de propriedade rural deficitária, via procedimento de compensação ambiental.

Considerando as discussões jurídicas em torno do instrumento alhures, cabe a problemática: A Cota de Reserva Ambiental é um presente para a presente e futura geração, na presente configuração legislativa em que foi confirmada a sua constitucionalidade pelo Supremo Tribunal Federal?

Tendo como objetivo geral analisar as principais teses aludidas nas ações diretas a favor e contra a constitucionalidade da cota, num primeiro momento o presente artigo aborda os principais aspectos derivados da normatização da Cota de Reserva Ambiental no atual Código Florestal, evoluindo a argumentação para a análise dos macro-argumentos prós e contra o instrumento aduzidos nas ações diretas.

Enfim, considerando a recente decisão final do Supremo Tribunal Federal quanto à constitucionalidade da Cota de Reserva Ambiental, o que se antevê é a manutenção de uma insegurança jurídica na utilização deste instrumento, que como seu antecessor pode se tornar inócuo. 


\section{COTA DE RESERVA AMBIENTAL (CRA)}

Há de se ponderar que a Cota de Reserva Ambiental não é uma inovação introduzida pelo vigente Código Florestal ao ordenamento jurídico nacional, haja vista este instrumento ser um sucedâneo da extinta Cota de Reserva Florestal, inclusa pela Medida Provisória no 2.166-67/2001 ao revogado Código Florestal (Lei no 4.771/1965).

Em comum, os instrumentos acima externalizam a possibilidade de que o proprietário de imóvel rural utilize uma fração de área verde especialmente tutelada e devidamente especificada pela legislação como um título representativo, que pode ser negociado no bojo de um procedimento para a compensação ambiental de área em déficit ambiental.

A Cota de Reserva Florestal não alcançou uma plena aplicabilidade prática, em decorrência, sobretudo, pela falta de regulamentação complementar ${ }^{4}$ e informações claras para a operacionalidade do mesmo e segurança jurídica nas negociações. O próprio Código Florestal de 1965, no artigo 44-b5 , que normatiza a Cota de Reserva Florestal, não era pragmático e, mesmo em outros momentos do texto do códex em referência, não foi possível se vislumbrar elementos objetivos suficientes para compreender a instrumentalização da cota.

Outrossim, tinha também o fato de serem extremamente restritas as opções de uso da Cota de Reserva Florestal. O artigo 44, inciso III e §5º, do Código Florestal de 1965, determinava que a compensação ambiental, utilizando a Cota de Reserva Florestal, prescindiria de prévia aprovação pelo órgão ambiental competente. Neste caso, o órgão ambiental deveria avaliar se as áreas permutadas eram equivalentes em extensão e importância ecológica, e se pertenciam ao mesmo ecossistema e a mesma microbacia.

Indubitável o ganho ecológico com condicionantes tão específicas - sobretudo a das áreas estarem na mesma microbacia -, mas elas foram tão limitadoras que tornaram a medida impraticável, tanto pela infraestrutura técnica, operacional e financeira das partes envolvidas (inclusive a do próprio Poder Público) quanto pela escassez de oportunidades para o uso da mesma.

Somando isso a outras situações e buscando mecanismos de desenvolvimento econômico sustentável, no projeto do novo Código Florestal brasileiro, houve um up grade (que se frisa não foi perfeito) neste instrumento para que ele realmente seja uma opção exequível e próspera, tanto para os particulares quanto para o Poder Público.

Dispõe o vigente Código Florestal (Lei no 12.651, de 25 de maio de 2012), no artigo 44, que a Cota de Reserva Ambiental corresponde a um título representativo nominativo. Ou seja, é um instrumento econômico de fim socioambiental que possui natureza jurídica de título de crédito.

Logo, para que o exercício do direito literal e autônomo constante nele tenha eficácia plena, é necessário que sejam satisfeitos os requisitos legais e a observância de que foi emitido em favor de pessoa cujo nome conste no registro do emitente (artigos 887 e 921 do Código Civil).

Lehfeld et. al. (2015, p. 259) explicam que o objetivo da Cota de Reserva Ambiental é ser um título negociável num Mercado próprio, tendo como demandante àquele que optou por utilizar a compensação como medida para regularizar ambientalmente sua propriedade rural. Para explicar a relação de oferta e demanda no âmbito da Cota de Reserva Ambiental, os

4 Inclusive, até o Projeto de Lei n⿳0 5.876/2005 de autoria do deputado Luciano Castro do Partido Liberal do Estado de Roraima, que visava operacionaliza a Cota de Reserva Florestal, foi arquivado em 31/o1/2012 - antes mesmo da vigência do Código Florestal de 2012. 5 Código Florestal de 1965, "Art. 44-b. Fica instituída a Cota de Reserva Florestal - CRF, título representativo de vegetação nativa sob regime de servidão florestal, de Reserva Particular do Patrimônio Natural ou reserva legal instituída voluntariamente sobre a vegetação que exceder os percentuais estabelecidos no art. 16 deste Código. Parágrafo único. A regulamentação deste Código disporá sobre as características, natureza e prazo de validade do título de que trata este artigo, assim como os mecanismos que assegurem ao seu adquirente a existência e a conservação da vegetação objeto do título." 
autores utilizaram o seguinte raciocínio: de um lado está o proprietário de imóvel rural, que mesmo não estando obrigado legalmente, opta por um benefício ambiental e, por isso, recebe um título que lhe reconhece um "crédito ambiental". Ao revés, está àquele que não respeitou a exigência ambiental legal (como atender ao mínimo de Área de Reserva Legal) e, por estar em "débito ambiental", adquire o título para compensar o prejuízo causado.

Importante colacionar que a "CRA se difere da compensação provinda da compra de terras florestadas pois trata-se de um tipo de Servidão Ambiental onde o vendedor do contrato da CRA se compromete em manter a cobertura vegetal da área durante o período de vigência do contrato. " (RAJÃO, 2015, p. 5)

Há, portanto, uma relação negocial, que tem por objeto a proteção de algumas áreas verdes ainda não devastadas (embora legalmente seria permitida a interferência), obrigando àqueles que infringiram os percentuais legais de proteção ambiental a se regularizarem valendo-se do pagamento daqueles que suportaram o custo oportunidade.

Neste interim, não obstante a importância basilar dos princípios ${ }^{6}$ decorrentes do artigo 225 da Constituição da República Federativa do Brasil de 19887, e que o princípio do protetorrecebedor $^{8}$ e do poluidor-pagador se concatenam para a formação da estrutura da Cota de Reserva Ambiental, observa-se que a ideologia deste instrumento está mais concentrada no primeiro.

Isso porque, o princípio do protetor-recebedor (também denominado preservadorrecebedor ou protetor-beneficiário) "se esteia na ideia fundamental de que não basta punir as condutas ambientalmente danosas para preservar com eficácia o meio ambiente, sendo mais produtivo recompensar as virtuosas" (MILARÉ, 2015, p. 271). Deste modo, o princípio em epígrafe visa que a consciência ambiental (e as atitudes advindas) seja reconhecida, valorada, valorizada, recompensada e difundida.

Altmann reforça que não se trata de simplesmente premiar aquele que cumpre com as obrigações legais de preservação, o princípio do preservador-recebedor vai além, pois "pugna pela recompensa daqueles que, mesmo tendo a oportunidade de agir diferente, optam por empreender esforços conservacionistas", beneficiando toda a coletividade. (2012, p. 156).

Conforme o artigo 44 e incisos do Código Florestal de 2012, as hipóteses de incidência para a emissão da Cota de Reserva Ambiental são em: (i) área sob regime de Servidão Ambiental, conforme o art. 9-9-A da Lei n 6.938/1981; (ii) sobre a área excedente de Reserva Legal constituída voluntariamente, observados os novos percentuais elencados no artigo 12 do vigente Código Florestal; e (iii) as áreas de Reserva Particular do Patrimônio Natural, nos moldes do artigo 21 da Lei no 9.985/200o. E diferente do Código antecessor, também poderá ser expedida a cota para (iv) área existente em propriedade rural localizada no interior de Unidade de Conservação de domínio público que ainda não tenha sido desapropriada.

No (i) regime de Servidão Ambiental, o proprietário de imóvel rural (pessoa física ou jurídica) limita o uso de sua propriedade com intuito de conservar ou recuperar os recursos ambientais ali existentes. Ou seja, "o proprietário ou possuidor, instituindo a servidão, abre mão da exploração da área total ou parcial do imóvel, ficando impedido de explorar economicamente seus recursos florestais. " (LEHFELD et. al., 2015, p. 260)

\footnotetext{
6 Em comum, Milaré (2015) e Machado (2013) mencionam os princípios do meio ambiente ecologicamente equilibrado, da prevenção, da precaução, do poluidor-pagador, do usuário-pagador, da participação comunitária.

7 "Após a constitucionalização da matéria ambiental no art. 225 da Constituição Federal de 1988, internaliza-se um novo objetivo às funções estatais: a proteção do meio ambiente", sendo imposto ao Estado como um critério de aferição de suas decisões e, inclusive, altera o pilar democrático, com o enfraquecimento da democracia representativa em detrimento da democracia direta ou participativa nas questões ambientais, dado que elas se prologam por períodos superiores ao do mandato dos representantes no poder." (CARVALHO, 2017, p. 112)

$8 \mathrm{~A}$ incorporação legal do princípio do protetor-recebedor pode-se considerar recente, haja vista que sua primeira menção expressa foi no artigo 6⿳⺈, inciso II, da Lei de Política Nacional de Resíduos Sólidos (Lei ㄲo 12.305/2010).
} 
Quanto a (ii) Área de Reserva Legal9 é essencial compreender que o artigo 12 e incisos do Código Florestal institui a obrigatoriedade de o proprietário rural destinar uma parcela do imóvel com vegetação nativa. Se o imóvel rural estiver localizado no interior da Amazônia Legal, e em áreas de florestas, a extensão territorial a ser cedida deverá observar o percentual mínimo de $80 \%$, 35\% se for área de Cerrado e $20 \%$ se for área de Campos Gerais; e para as demais regiões do país será aplicado o percentual de $20 \%$. Portanto, para fins de emissão de Cota de Reserva Ambiental, ela apenas será emitida na extensão de Área de Reserva Legal, voluntariamente instituída pelo proprietário, que exceder aos percentuais mínimos legais.

Destaca-se que a utilização da Cota de Reserva Ambiental para compensação de Área de Reserva Legal apenas é permitida se o imóvel rural beneficiário estiver situado no mesmo bioma da área do título, for atendido os requisitos do artigo 66, §6 do Código Florestal e providenciada a averbação do título, tanto na matrícula do imóvel rural cedente quanto no beneficiado (artigo 48, $\S \S 2^{\circ}, 3^{\circ}$ e $4^{\circ}$ do Código Florestal).

A (iii) Reserva Particular de Patrimônio Natural (RPPN) corresponde a uma área privada cedida espontaneamente pelo proprietário para a conservação da diversidade biológica, que será gravada com perpetuidade mediante Termo de Compromisso firmado pelo proprietário perante o órgão ambiental, conforme o artigo 21 do Código Florestal e o Decreto no 5·746/2006 (responsável pela regulamentação do instituto).

No que tange a hipótese de emissão de cota ambiental em (iv) a área localizada no interior da Unidade de Conservação de domínio público e de propriedade particular que ainda não foi desapropriada, inconteste a necessidade de desapropriação do grupo de Unidades de Conservação de Proteção Integral pelo Poder Público. Haja vista a incompatibilidade da manutenção deáreas particulares localizadas no interior da Estação Ecológica, Reserva Biológica e Parque Nacional - que são de posse e domínio público.$^{10}$ Ressalva-se que nos territórios de Monumento Natural e Refúgio da Vida Silvestre poderão coexistir áreas particulares, apenas se forem destinadas para a proteção ambiental, nos moldes da legislação em vigor (subsistindo conjuntamente o domínio privado e/ou público). ${ }^{11}$

Além de estar entre as hipóteses taxativas explicitadas no artigo 44, incisos I ao IV, do Código Florestal de 2012, a Cota de Reserva Ambiental deverá abranger área com vegetação nativa, existente ou em processo de recuperação. Para tornar ainda mais claro, o artigo 46, do mesmo diploma legal, explica que uma cota corresponderá a 1 (um) hectare de: "I - de área com vegetação nativa primária ou com vegetação secundária em qualquer estágio de regeneração ou recomposição; II - de áreas de recomposição mediante reflorestamento com espécies nativas".

Um ponto inaugural e muito debatido em torno da regulamentação da Cota de Reserva Ambiental no Código Florestal de 2012 é a possibilidade de a cota ser negociada para a compensação ambiental de área em propriedade (deficitária) que esteja no mesmo bioma da propriedade (superavitária) que ensejou a cota, porém localizadas em pontos geográficos muito distantes (artigo 66, §6으). A ressalva é feita porque o Brasil é um país de extensão continental e um mesmo bioma pode abranger Estados federados diferentes ou Municípios equidistantes, sendo possível que a cota seja negociada em nível interestadual ou intermunicipal.

Seguindo, é possível que a Cota de Reserva Ambiental seja transferida, a título oneroso ou gratuito, para pessoa física ou jurídica, esta última de direito público ou privado, mediante Termo assinado pelo titular do título e pelo adquirente, com pleno efeito após o registro no sistema único de controle de cota (art. 48, caput e §ュº do Código Florestal).

9 O Código Florestal de 2012 conceitua no artigo 3ㅜㅜ, inciso III, "Reserva Legal: área localizada no interior de uma propriedade ou posse rural, delimitada nos termos do art. 12, com a função de assegurar o uso econômico de modo sustentável dos recursos naturais do imóvel rural, auxiliar a conservação e a reabilitação dos processos ecológicos e promover a conservação da biodiversidade, bem como o abrigo e a proteção de fauna silvestre e da flora nativa."

10 Vide artigos $9^{\circ}$, $\S_{1}{ }^{\circ} ; 10, \S_{1}{ }^{\circ}$ e 11, $\S_{1}{ }^{\circ}$, da Lei nº 9.985/200o.

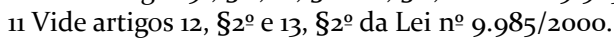


O proprietário rural que estiver interessado na emissão de cota deverá comprovar, cumulativamente, que o imóvel está incluso no Cadastro Ambiental Rural (CAR) e que possui o laudo comprobatório de que a área pretendida à cotização se enquadra em alguma das hipóteses legais - o qual deve ser emitido por entidade credenciada ou pelo próprio órgão ambiental destinatário do pedido (artigo 44, §1ำ e 45 do Código Florestal).

Frisa-se que não se estende ao possuidor do imóvel a legitimidade para fazer o requerimento de emissão da cota ao órgão ambiental competente do Sistema Nacional do Meio Ambiente (SISNAMA), em razão da segurança jurídica e dos próprios poderes inerentes ao direito de propriedade.

E para resguardar a segurança nas contratações, tendo como objeto cotas ambientais, $o$ legislador estabeleceu taxativamente as hipóteses de seu cancelamento que, frisa-se, também deverá ser averbada no imóvel de origem da cota. São elas: (a) por solicitação do proprietário rural, em caso de desistência na manutenção das áreas nos termos do artigo 44, incisos I e II (regime de Servidão Ambiental e excedente de área de Reserva Legal, respectivamente); (b) automaticamente, por causa do término do prazo de Servidão Ambiental; ou (c) "por decisão do órgão competente do SISNAMA, no caso de degradação da vegetação nativa da área vinculada à CRA cujos custos e prazo de recuperação ambiental inviabilizem a continuidade do vínculo entre a área e o título"12 (artigo 50, incisos I a III do Código Florestal).

De fato, a normatização da Cota de Reserva Ambiental, no Código Florestal de 2012, mostra-se mais promissora do que a da Cota de Reserva Florestal, prevista no Código Florestal 1965 .

Não obstante o Código Florestal de 2012 ter apresentado maiores instruções sobre o que é e como deve se operacionalizar a Cota de Reserva Ambiental, há muitas lacunas e complementações que precisam ser feitas, bem como, ponderações para a real efetivação do instrumento e mensuração dos benefícios socioambientais que este poderá trazer ao regime de proteção ambiental.

Principalmente porque a redação do Código Florestal de 2012, em diversas partes, possui influências (notórias) do agronegócio, em sobreposição ao meio ambiente ecologicamente equilibrado intergeracional. Embora os dados a seguir estejam relacionadas as legislaturas pósvotação do Código Florestal de 2012, a situação fática era similar.

Conforme os dados disponibilizados pela Frente Parlamentar da Agropecuária (FPA) atualmente a bancada conta com 209 deputados federais e 27 senadores federais, em exercício. (FRENTE PARLAMENTAR AGROPECUÁRIA, 2018?). Considerando que a Câmara dos Deputados é composta por 513 deputados federais, a bancada ruralista representa, portanto, cerca de $40,7 \%$ das opiniões que decidirão o futuro do país; e no Senado Federal, composto por 81 senadores, a bancada alcança $33,3 \%$.

Esses entremeios em torno da elaboração e aprovação do Código Florestal de 2012, ensejou várias discussões constitucionais sobre alguns dispositivos deste diploma legal, no âmbito do Supremo Tribunal Federal, que levaram aproximadamente cinco anos para serem decididas, e que mesmo assim ainda fomentam questionamentos. E entre os tópicos debatidos está a Cota de Reserva Ambiental.

12 Neste caso, o cancelamento da cota independe da aplicação das respectivas sanções administrativas e penais decorrentes de infração à legislação ambiental, nos moldes da Lei no 9.605/1998 (artigo 5o, §ºํ do Código Florestal). 


\section{A COTA DE RESERVA AMBIENTAL NO SUPREMO TRIBUNAL FEDERAL}

O debate jurídico e político em torno da Lei no 12.651, de 25 de maio de 2012, tendo como nomen juris Código Florestal, alcançou a máxima proporção com a propositura' ${ }^{13}$ das seguintes ações, dirigidas ao Supremo Tribunal Federal ${ }^{14}$ : (i) Ações Diretas de Inconstitucionalidade (ADI) 4901, 4902 e 4903, todas com pedido de medida cautelar para a suspensão da eficácia dos dispositivos impugnados até a efetiva sentença, propostas em 21/03/2013, pela ProcuradoraGeral da República Sandra Cureau; (ii) ADI 4937, proposta pelo Partido Socialismo e Liberdade (PSOL) e autuada no dia 04/04/2013.

A ADI é uma ação objetiva em que se impugna a validade constitucional de um ato normativo, in casu, dispositivos do Código Florestal de 2012. Por conseguinte, não há que se falar em processo subjetivo em que impera o contraditório entre litigantes acerca de um direito particular violado, não havendo um réu na ação.

As partes protagonizam a disputa processual pela definição da compatibilidade da norma impugnada com a Constituição da República, contudo os direitos e deveres individuais existentes em função de declaração - ou não - de validade da norma genérica derivam da própria norma ou do regime jurídico remanescente, e não diretamente da decisão judicial. (MENEZES, 2012, p. 80)

Embora não tenha total esteio técnico, como bem assevera MENEZES (2012, p. 84), para fins processuais (meramente formais), pode-se considerar como legitimado passivo na ação direta constitucional àquele que será intimado pelo Ministro Relator do processo para prestar informações sobre o dispositivo ora impugnado.

E nas ações diretas em epígrafe, concentradas na Relatoria do Ministro Luiz Fux, em razão da conexão e prevenção ${ }^{15}$ (as demais ações foram apensadas à ADI 4901), há o litisconsórcio passivo entre o Presidente da República e o Congresso Nacional, ambos representados pelo Advogado-Geral da União' ${ }^{16}$.

Outros dados importantes sobre estas ações diretas são: (i) o pedido de medida cautelar para a suspensão da eficácia dos dispositivos impugnados foi indeferido, sob a alegação da

13 Os legitimados ativos para a propositura de ações diretas constitucionais podem ser divididos em dois tipos, os universais (artigo 103, incisos I, II, III, VI, VII e VIII da Constituição Federal de 1988) e os especiais (artigo 103, incisos IV, V e IX, da Constituição Federal de 1988). Em especial, compõe os legitimados ativos universais o Procurador-Geral da República (vide também o artigo $2^{\circ}$, inciso VI, da Lei no 9.868/99) e o Partido Político com representação no Congresso Nacional (vide também artigo 2º, inciso VIII, da Lei no 9.868/99). Diferente dos legitimados especiais, os universais estão eximes da comprovação de pertinência temática para a propositura da ação, pois "são considerados interessados em toda ordem jurídica nacional, com atribuição de zelar pela supremacia constitucional, em razão de suas próprias atribuições constitucionais, pelo que podem provocar a verificação de compatibilidade de qualquer ato normativo federal ou estadual em face da Constituição da República. " (MENEZES, 2012, p. 83) Importante anotar que a pertinência temática funciona como uma espécie de filtro processual-constitucional direcionado aos legitimados ativos, visando coibir proposituras abusivas de ADIs tendo como objeto atos normativos que em nada se relacionam com as suas respectivas esferas de atuação e/ou interesse técnico, político, jurídico e social.

14 Oartigo 102, inciso I, alíneasa ep, da Constituição da República Federativa do Brasil de 1988, dispõeque competeao Supremo Tribunal Federal processar e julgar, originariamente, a Ação Direta de Inconstitucionalidade e Ação Declaratória de Constitucionalidade de lei ou ato normativo, tal como, o pedido de medida cautelar que esta ação possa ter.

15 Considerando que a propositura das ações foi em data anterior à vigência da atual legislação processual civil (Lei no 13.105/2015), se fará a remissão ao revogado Código para a explicação dos institutos processuais.

A conexão processual ocorre quando duas ou mais ações, em curso, possuem em comum o objeto ou a causa de pedir (artigo 103 do Código de Processo Civil de 1973). Para compreender a atual regulamentação do instituto, vide o artigo 55, caput do Código de Processo Civil de 2015.

A prevenção processual visa que ações conexas, distribuídas para juízos diferentes, sejam julgadas pelo mesmo juiz, para manter a segurança jurídica nas decisões. Se os juízes forem da mesma competência territorial, o juiz prevento será àquele que despachou primeiro, mas se forem de competência territorial diversa, será aquele que recebeu primeiro a citação válida; deste modo, as demais ações (as que estão em curso ou que ainda serão distribuídas) deverão ser direcionadas ao juiz prevento (artigo 106 e 219 do Código de Processo Civil de 1973). Para compreender a atual regulamentação do instituto, vide o artigo 43 e 59 do Código de Processo Civil de 2015.

16 Não obstante a autonomia funcional (vide ADI 3916/DF), o Advogado Geral da União, via de regra, tem a sua atuação prelecionada a defender o dispositivo impugnado na ADI, por isso pode ser denominado como o "curador da presunção de constitucionalidade dos atos normativos." (MENEZES, 2012, p. 468). 
necessidade de adoção do procedimento disposto no artigo 12 da Lei no 9.868/1999; (ii) foi admitida a intervenção de amicus curiae ${ }^{17}$; e (iii) realizada Audiência Pública no dia 18/04/2016.

Os dispositivos do Código Florestal de 2012 questionados nas ações diretas são, na (i)

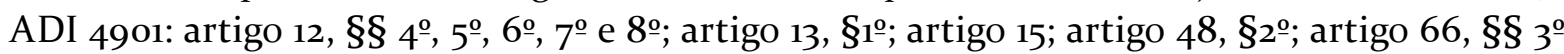
e $5^{\circ}$, incisos II, III e IV e $§ 6^{\circ}$; artigo 68. Na (ii) ADI 4902: artigo $7^{\circ}$, $§ 3^{\circ}$; artigo 59 , $\S \S 4^{\circ}$ e $5^{\circ}$; artigo 6o; artigo 61-A; artigo 61-B; artigo 61-C; artigo 63; artigo 67; artigo 78-A. Na (iii) ADI 4903: artigo $3^{\circ}$, inciso VIII, alínea $\mathrm{b}$, incisos IX, XVII, XIX e parágrafo único; artigo $4^{\circ}$, incisos

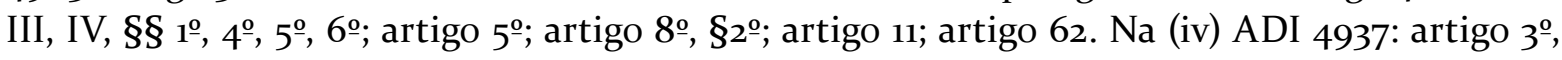

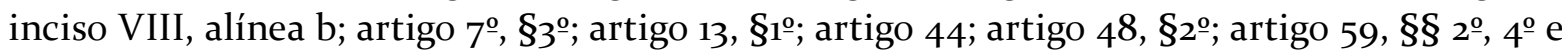
$5^{\circ}$; artigo 61-A; artigo 61-C; artigo 63.

Em síntese, todos os proponentes das ADIs alegam que as normas elencadas nas petições iniciais são inconstitucionais, pois violam o disposto no artigo 225 da Constituição Federal de 1988. A Procuradora-Geral da República ainda menciona um ultraje ao artigo $5^{\circ}$, caput e o artigo 186, incisos I e II, ambos da Constituição Federal de 1988.

A tramitação destas ações diretas foi morosa, diga-se de passagem. Após, aproximadamente, cinco anos (contados da data da protocolização à sentença), no dia 28/02/2018 o Plenário do Supremo Tribunal Federal se reuniu para julgar parcialmente procedentes as ações.

A configuração das decisões ficou, em relação a ADI 4901, da seguinte forma: (a)

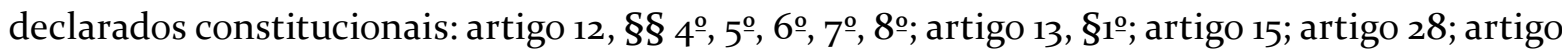
66 , $§ \S 3^{\circ}, 5^{\circ}, 6$; ; artigo 67; artigo 68; e (b) dar interpretação conforme a Constituição ao artigo $48, \S 2^{2}$, "para permitir compensação apenas entre áreas com identidade ecológica."

Na ADI 4902, (a) declarados constitucionais: artigo $7^{\mathbf{0}}$; artigo 17, §3ㅜㅜ artigo 6o; artigo 61-A; artigo 61-B; artigo 61-C; artigo 63; artigo 67; artigo 78-A. E (b) dar interpretação conforme a Constituição ao artigo 59, $§ \S 4^{\mathbf{0}^{18}}$ e $5^{\mathbf{0 1 9}}$.

Para a ADI 4903, foram (a) declarados constitucionais: artigo $3^{\circ}$, inciso XIX; artigo

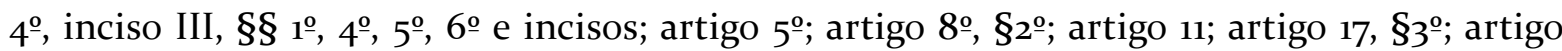
62. Para (b) dar interpretação conforme a Constituição ao: artigo $3^{\circ}$, incisos VIII e IX ${ }^{20}$ e ao inciso XVII ${ }^{21}$; artigo $4^{\circ}$, inciso $\mathrm{IV}^{22}$. E (c) declarados inconstitucionais: "as expressões 'gestão de resíduos' e 'instalações necessárias à realização de competições esportivas estaduais, nacionais ou internacionais', contidas no artigo $3^{\circ}$, inciso VIII, alínea b; “as expressões 'demarcadas' e 'tituladas', contidas no artigo $3^{\circ}$, parágrafo".

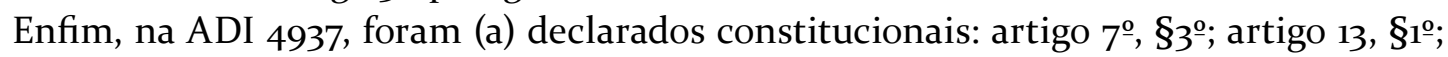
artigo 44; artigo 6o; artigo 61-A; artigo 61-B; artigo 61-C; artigo 63. Para (b) dar interpretação conforme a Constituição ao: artigo 48, $§ 2^{\circ}$, "para permitir compensação apenas em áreas com identidade ecológica"; artigo 59, §§ $4^{\mathbf{0 2 3}}$ e $5^{\underline{024}}$. E (c) declarados inconstitucionais: "as expressões

17 No despacho publicado em 15/o8/2013, afirma o Ministro Relator Luiz Fux: "Isso porque, a despeito de sua tradicional qualificação como processo objetivo [ADI], o controle concentrado e abstrato de constitucionalidade não deve se cingir apenas ao mero cotejo de diplomas normativos, mas também deve considerar o cenário fático sobre o qual incide a norma objurgada, ampliando o acesso à jurisdição constitucional a novos atores que, em alguma medida, sejam afetados em sua esfera jurídica. Com efeito, o telos precípuo da intervenção do amicus curiae consiste na pluralização do debate constitucional, com vistas a municiar a Suprema Corte dos elementos informativos possíveis e necessários ou mesmo trazer novos argumentos para o deslinde da controvérsia, superando, ou senão amainando, as críticas concernentes à suposta ausência de legitimidade democrática de suas decisões. ” (STF, ADI 4901, p. 1) 18 "De modo a afastar, no decurso da execução dos termos de compromissos subscritos nos programas de regularização ambiental, o risco de decadência ou prescrição, seja dos ilícitos ambientais praticados antes de 22.07.2008, seja das sanções deles decorrentes, aplicando-se extensivamente o disposto no §1ํㅡㄹ do artigo 6o da Lei no 12.651/2012, segundo o qual 'a prescrição ficará interrompida durante o período de suspensão da pretensão punitiva'."

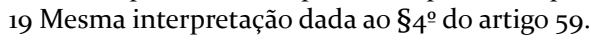

20 "De modo a se condicionar a intervenção excepcional em APP [Área de Preservação Permanente], por interesse social ou utilidade pública, à inexistência de alternativa técnica proposta. "

21 "Para fixar a interpretação de que os entornos das nascentes e dos olhos d'água intermitentes configuram APP."

22 Mesma interpretação dada ao inciso XVII, do artigo $3^{\circ}$.

23 Mesma interpretação dada ao §4º do artigo 59.

24 Mesma interpretação dada ao $\$ 4^{\circ}$ do artigo 59 . 
'gestão de resíduos' e 'instalações necessárias à realização de competições esportivas estaduais, nacionais ou internacionais', contidas no artigo $3^{\circ}$, inciso VIII, alínea b.

Há de se destacar que também estava em tramitação, desde o8/04/2016, a Ação Declaratória de Constitucionalidade (ADC) proposta pelo Partido Progressista (PP), que em direção contrária às ações diretas alhures, solicitava a constitucionalidade de todos os dispositivos do Código Florestal impugnados. As mesmas observações realizadas para as ADIs 4901, 4902, 4903 e 4937 (corroborado pelo fato dela ter sido apensada à ADI 4901, em virtude da prevenção), inclusive quanto a decisão de mérito, se estende a essa ADC.

Neste panorama, concentrando-se na Cota de Reserva Ambiental, é possível delimitar a pesquisa às ADIs 4901 e 4937 (sobretudo à última), que confrontaram os dispositivos artigos

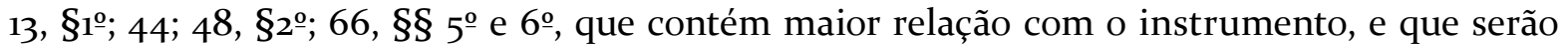
analisados de forma geral a seguir.

\section{1 (Des)pacificação jurisdicional sobre a Cota de Reserva Ambiental}

Não obstante o artigo 44 do Código Florestal de 2012, que baliza a Cota de Reserva Ambiental, ter sido unanimemente julgado constitucional pelos Ministros do Supremo Tribunal Federal em 2018, ainda persistem questionamentos (sobretudo, para a aplicação prática) relacionados ao instrumento.

Inclusive é possível extrair das próprias teses levantadas nas ações diretas em comento, as críticas (que se mantém) quanto a interpretação e a implementação da Cota de Reserva Ambiental. E, curiosamente, tais críticas utilizaram argumentos que foram igualmente aduzidos pelas partes contrapostas. Obviamente, cada qual endossando a sua opinião.

É o que se verifica com o (a) princípio da função socioambiental da propriedade, isso porque, se, por um lado, a Cota de Reserva Ambiental poderá causar a especulação imobiliária das propriedades rurais; por outro, é mais uma fonte de renda para os proprietários rurais, sobretudo àqueles com pequena propriedade de até quatro módulos fiscais.

Em relação ao (b) dever geral de proteção e reparação ambiental, pondera-se que no procedimento de compensação ambiental, via Cota de Reserva Ambiental, o requisito da permutação de áreas do mesmo bioma é insuficiente e a comercialização desses títulos entre Estados diferentes prejudica o meio ambiente regional. De outra parte, o instrumento possibilitará a expansão de grandes áreas de proteção ambiental e o gerenciamento integrado dos espaços ambientalmente protegidos.

E quanto ao (c) princípio da vedação de retrocesso socioambiental, constatado de forma mais implícita nos argumentos, haveria indícios de que a atual legislação ambiental é menos protetiva do que a lei revogada, implicando diretamente na normatização da Cota de Reserva Ambiental. No entanto, o título apenas poderá ser emitido sobre o excedente legal de áreas ambientalmente protegidas e para a compensação ambiental de áreas desmatadas até o dia 22/07/2008.

Urge compreender que "a importância da noção de função socioambiental da propriedade se manifesta, sobremaneira, na percepção de que a interferência na propriedade não é interferência no direito de propriedade, quando proveniente da função social, posto que é a própria configuração desse direito" (MANGUEIRA, 2000, p. 233), razão que legitima a interferência do Poder Público na esfera privada, em prol do interesse da coletividade presente e futura.

O artigo 186, incisos I ao IV, da Constituição Federal de 1988, estabelece que a função socioambiental da propriedade rural apenas será configurada se, simultaneamente e 
em conformidade com os critérios e graus dispostos em lei, forem cumpridos os requisitos do(a): (i) aproveitamento racional e adequado; (ii) utilização adequada dos recursos naturais disponíveis e preservação da natureza; (iii) observância das normas trabalhistas nas relações empregatícias; (iv) exploração que favoreça o bem-estar dos proprietários e trabalhadores.

Destarte, o proprietário rural possui limitações de ordem pública e coletiva ao direito de uso e exploração de sua propriedade. E no caso de não serem observadas tais condicionantes sociais e ambientais, elas implicarão na necessária regularização ambiental do imóvel, via administrativa ou judicial, que na hipótese de compensação ambiental, dentre os métodos disponíveis, o proprietário poderá utilizar a Cotas de Reserva Ambiental.

Neste ponto, alguns vislumbram que a implementação da Cota de Reserva Ambiental será uma nova fonte de renda para os pequenos proprietários rurais, pois poderão comercializar as florestas e vegetações nativas superavitárias mantidas no imóvel rural, haja vista o disposto no art. 44, §4 ${ }^{\circ}$ do Código Florestal. Frisa-se que conforme os dados do Sistema Nacional de Cadastro Rural (SNCR), disponibilizado pelo Instituto Nacional de Colonização e Reforma Agrária (INCRA), no ano de 2016, contabilizou-se mais propriedades rurais com até 4 módulos fiscais de titularidade privada (total de 5.232.019), do que aquelas na faixa acima de 4 até 600 módulos ficais (534.523). (INCRA, 2016).

O Código Florestal de 2012 dispensa a pequena propriedade rural ${ }^{25}$ do cumprimento integral dos atuais percentuais legais de Ârea de Reserva Legal, independentemente de adesão ao Programa de Regularização Ambiental. Bem como, de recompô-la, devendo apenas manter o remanescente de vegetação nativa existente em 22/07/2008 e não realizar novas conversões da área para uso alternativo do solo (artigo 3º, parágrafo único e artigo 67, ambos do Código Florestal ${ }^{26}$ ).

Sobre esta previsão, mister elucidar o Agravo em Recurso Especial no 1.149.867 - MG (2017/0197092-6), interposto em 25/05/2017, no Superior Tribunal de Justiça, contra decisão do Tribunal de Justiça do Estado de Minas Gerais. Embora o Superior Tribunal de Justiça não tenha se debruçado na época a análise do artigo 68 do Código Florestal, é possível extrair que em sede de controle incidental tal dispositivo foi declarado inconstitucional pelo Tribunal de Justiça de Minas Gerais, pelas razões a seguir destacadas na decisão ministerial.

EMENTA:APELAÇÃO CÍVEL. EMBARGOSÀ EXECUÇÃO. PRELIMINAR. INSTALAÇÃO DE INCIDENTE DE INCONSTITUCIONALIDADE. REJEIÇÃO. AVERBAÇÃO DA ÁREA DE RESERVA LEGAL NA MATRÍCULA DO IMÓVEL. SUPERVENIÊNCIA DA LEI 12.651, DE 2012. [...] Com efeito, a Corte de origem, ao analisar a controvérsia, asseverou que o art. 67 da Lei 12.651/2012 teve sua inconstitucionalidade declarada, em sede de controle incidental de inconstitucionalidade, considerando "a existência do direito adquirido em caráter ambiental difuso, resultante do regime de proteção anterior que estabeleceu a obrigatoriedade da reserva legal como direito subjetivo da coletividade, com base em que não pode a Lei Nova reduzir o âmbito de proteção a que se

25 Conceitua o Código Florestal de 2012, no artigo $3^{\circ}$, inciso V, "pequena propriedade ou posse rural familiar: aquela explorada mediante o trabalho pessoal do agricultor familiar e empreendedor familiar rural, incluindo os assentamentos e projetos de reforma agrária, e que atenda ao disposto no art. $3^{\circ}$ da Lei $n^{\circ} 11.326$, de 24 de julho de 2006 ."

E conforme a Lei no 11.326/2006: "Art. $3^{\circ}$. Para os efeitos desta Lei, considera-se agricultor familiar e empreendedor familiar rural aquele que pratica atividades no meio rural, atendendo, simultaneamente, aos seguintes requisitos: I - não detenha, a qualquer título, área maior do que 4 (quatro) módulos fiscais; II - utilize predominantemente mão-de-obra da própria família nas atividades econômicas do seu estabelecimento ou empreendimento; III - tenha percentual mínimo da renda familiar originada de atividades econômicas do seu estabelecimento ou empreendimento, na forma definida pelo Poder Executivo; V - dirija seu estabelecimento ou empreendimento com sua família."

26 O Código Florestal dispõe no artigo 3ํㅜ, parágrafo único, "Para os fins desta Lei, estende-se o tratamento dispensado aos imóveis a que se refere $o$ inciso $\mathrm{V}$ deste artigo às propriedades e posses rurais com até 4 (quatro) módulos fiscais que desenvolvam atividades agrossilvipastoris, bem como às terras indígenas demareadas e às demais áreas tituladas de povos e comunidades tradicionais que façam uso coletivo do seu território."

E no artigo 67, que "Nos imóveis rurais que detinham, em 22 de julho de 2008, área de até 4 (quatro) módulos fiscais e que possuam remanescente de vegetação nativa em percentuais inferiores ao previsto no art. 12, a Reserva Legal será constituída com a área ocupada com a vegetação nativa existente em 22 de julho de 2008 , vedadas novas conversões para uso alternativo do solo." 
destina o instituto" (fl. 299e). Asseverou que o aludido dispositivo legal "compromete o princípio da proteção o tratamento dispensado à reserva legal, para os imóveis cuja metragem seja de até quatro módulos fiscais, por consolidar a degradação ambiental já promovida em extensa quantidade de imóveis rurais, em manifesto retrocesso à tutela ambiental constitucional" (fl. 299e). Entretanto, tais fundamentos não foram impugnados pela agravante, nas razões do Recurso Especial. Portanto, incide, na hipótese, a Súmula 283/STF (...). (...) 5. Recurso especial conhecido em parte, e, nessa parte, parcialmente provido" (STJ, REsp 1299897/SC, Rel. Ministra ELIANA CALMON, SEGUNDA TURMA, DJe de 10/o5/2013). (STJ - AREsp: 1149867 MG 2017/0197092-6, Relator: Ministra Assusete Magalhães, Data da Publicação: DJ 24/10/2017) (Grifo nosso)

Não obstante os argumentos como os acima demonstrados e outros elencados nas ações diretas, o Supremo Tribunal Federal decidiu pela constitucionalidade do artigo 68 do Código Florestal de 2012. Deste modo, frisa-se, o pequeno proprietário rural deverá manter Área de Reserva Legal, mas podendo se valer do quantum ainda existente de vegetação nativa até a data de 22/07/2008, independente se está em percentual menor do que estipulado pelo Código Florestal de 2012 para o bioma do qual a propriedade pertence ${ }^{27}$ ou de recuperação da área degradada.

Sem muitas dificuldades, raciocina-se que: Se não há um quantum mínimo uniforme a ser resguardado pelas pequenas propriedades rurais para fins de Ârea de Reserva Legal, não há como mensurar um excedente disponível para futura emissão de Cota de Reserva Ambiental. Inclusive a própria Consultoria Legislativa da Câmara dos Deputados já havia concluído que tal possibilidade "parece um contrassenso, pois esse instrumento pode ser destinado à compensação de reserva legal inexistente em outra propriedade”. (JURAS e GANEM, 2012, p. 161)

E essa incerteza de como se avaliará o "excedente de área ambiental", para fins de emissão de Cota de Reserva Ambiental, na pequena propriedade rural persiste pós-decisão do Supremo Tribunal Federal, pois a constitucionalidade foi confirmada, sem ressalvas a este ponto.

Outrossim, com a desobrigação do pequeno proprietário rural à regularização ambiental da propriedade na atual configuração protetiva, há o desprivilegio àqueles que corretamente obedeceram aos percentuais legais vigentes a época. Ao passo que a alteração desincentiva a observância da norma por àqueles que a consideravam e, mais ainda, aos que já não a consideravam. Também diminui substancialmente as Âreas de Reserva Legal no país e prejudica os pequenos proprietários rurais a serem potenciais fornecedores de ativos florestais no Mercado de Cotas de Reserva Ambiental.

Aliás, o artigo 68, §1º ${ }^{\circ}$, do Código Florestal de 2012 instrui como os proprietários ou possuidores rurais poderão provar essas situações consolidadas ${ }^{28}$, seja através de documentos que constem "a descrição de fatos históricos de ocupação da região, registros de comercialização, dados agropecuários da atividade, contratos e documentos bancários relativos à produção, e por todos os outros meios de prova em direito admitidos". Todavia, inconteste as dificuldades em se efetivamente comprovar (tecnicamente e de forma menos dispendiosa) que a interferência na Área de Reserva Legal datou até 22/07/2008, estando comprometida uma avaliação precisa da extensão temporal e territorial da alteração antropogênica no meio ambiente local.

27 Inclusive, dispõe o artigo 68, § 2º , do Código Florestal que "os proprietários ou possuidores de imóveis rurais, na Amazônia Legal, e seus herdeiros necessários que possuam índice de Reserva Legal maior que 5o\% (cinquenta por cento) de cobertura florestal e não realizaram a supressão da vegetação nos percentuais previstos pela legislação em vigor à época poderão utilizar a área excedente de Reserva Legal também para fins de constituição de servidão ambiental, Cota de Reserva Ambiental - CRA e outros instrumentos congêneres previstos nesta Lei."

28 O Código Florestal de 2012 dispõe no artigo 3ํㅜ, inciso IV que área rural consolidada é a "área de imóvel rural com ocupação antrópica preexistente a 22 de julho de 2008 , com edificações, benfeitorias ou atividades agrossilvipastoris, admitida, neste último caso, a adoção do regime de pousio. ” 
Destarte não se pode ter uma segurança de que o instrumento realmente auxiliará os pequenos proprietários, por causa dos entraves lógicos que existem e persistem na normatização do instrumento, e igualmente que o meio ambiente local estará protegido, haja vista a dispensa de recomposição da Área de Reserva Legal pelas pequenas propriedades rurais.

Seguindo, outra crítica em torno da Cota de Reserva Ambiental que se pode extrair das discussões nas ações diretas é a de que ela favorecerá a especulação imobiliária. Isso porque se presume que as áreas economicamente improdutivas (desvalorizadas) é que serão utilizadas para comercialização de "florestas em pé", ao passo que àquelas com maior produtividade, os proprietários excluirão de pronto tal possibilidade. Por conseguinte, estes fatores irão influir diretamente no preço dos imóveis rurais.

A especulação imobiliária não é uma situação inaugurada com a implementação da Cota de Reserva Ambiental. Essa já uma realidade nacional, que pela ausência de uma correta regulamentação e fiscalização estatal, torna o Mercado de Terras um ambiente favorecedor da desigualdade social e da degradação ambiental. Reydon assevera que:

\begin{abstract}
Portanto, o que se faz necessário é regular para orientar parte da especulação, pois esta sempre existirá, o que não pode ser permitido é que, em nome da não-intervenção, apenas poucos se beneficiem de seu uso especulativo e além disso criem problemas econômicos, sociais e ambientais. A partir dessas constatações há necessidade de se regular efetivamente o mercado para seu melhor funcionamento e para coibir os excessos nos processos especulativos. (REYDON, 2007, p. 257)
\end{abstract}

É preciso reconhecer que a especulação imobiliária das propriedades rurais é uma situação que poderá ou não ser potencializada pela Cota de Reserva Ambiental, mas não por culpa do instrumento em si, mas sim, pela gestão ineficiente do Poder Público para controlar as variações de preço da terra.

Quanto ao dever geral de proteção e reparação ambiental pelo Poder Público, uma das alegações mais corriqueiras em desfavor da Cota de Reserva Ambiental está na possibilidade de o instrumento utilizar como requisito geral para a permutação entre as áreas, a identidade do bioma, ou seja, poderá haver contratações entre Município ou Estado diferente daquele que originou a cota. Por outro lado, fomenta a criação e manutenção de grandes espaços florestais e o gerenciamento mais integrado das áreas verdes especialmente tuteladas.

O Supremo Tribunal Federal ao mudar os critérios para a compensação ambiental de Área de Reserva Legal acabou criando aparentemente duas hipóteses de incidência para uma mesma situação. Isso porque, os Ministros decidiram que o critério de identidade entre biomas, disposto no artigo $48, \S_{2}{ }^{\circ}$ do Código Florestal, era muito amplo, devendo ser utilizada a cota apenas entre áreas com identidade ecológica. No entanto, o artigo 66, §5ํㅜ do Código Florestal $^{29}$ estabelece as modalidades de compensação ambiental, dentre elas está a Cota de Reserva Ambiental, e o $\$ 6^{030}$ deste mesmo artigo, declarado constitucional pela Suprema Corte, estabelece como critério de compensação as áreas estarem no mesmo bioma.

Deste modo, se for considerada a lógica do princípio da especialidade (preponderância da norma mais específica no conflito com a norma geral), no caso de compensação ambiental

\footnotetext{
29 Código Florestal, artigo 66, $\S 5^{\circ}$. "A compensação de que trata o inciso III do caput deverá ser precedida pela inscrição da propriedade no CAR e poderá ser feita mediante: I - aquisição de Cota de Reserva Ambiental - CRA; II - arrendamento de área sob regime de servidão ambiental ou Reserva Legal; III - doação ao poder público de área localizada no interior de Unidade de Conservação de domínio público pendente de regularização fundiária; IV - cadastramento de outra área equivalente e excedente à Reserva Legal, em imóvel de mesma titularidade ou adquirida em imóvel de terceiro, com vegetação nativa estabelecida, em regeneração ou recomposição, desde que localizada no mesmo bioma."

30 Código Florestal, artigo 66, §6ㅇ. "As áreas a serem utilizadas para compensação na forma do § 50 deverão: I - ser equivalentes em extensão à área da Reserva Legal a ser compensada; II - estar localizadas no mesmo bioma da área de Reserva Legal a ser compensada; III - se fora do Estado, estar localizadas em áreas identificadas como prioritárias pela União ou pelos Estados. ”
} 
via Cota de Reserva Ambiental, deverá ser utilizado o critério da identidade ecológica - embora ainda não possua uma definição clara.

Em relação a manutenção do critério entre identidades de biomas no procedimento de compensação ambiental - inclusive utilizando Cota de Reserva Ambiental, a ressalva a ser feita é que o questionamento acerca da possibilidade de permutação entre Estados federados persiste.

Todavia, realmente não deve prosperar o óbice inicial quanto a permutação de áreas via Cota de Reserva Ambiental, haja vista que as hipóteses são taxativas (vide por exemplo o artigo 16 e incisos do Decreto no $8.253 / 2014^{31}$ ) e funcionam como um critério para a gestão ambiental interfronteiras e extrafronteiras de recursos naturais de interesse regional, como se extrai do teor do artigo $66, \S 7^{\circ}$ do Código Florestal ${ }^{32}$ (que também teve sua constitucionalidade confirmada).

E mesmo que esta hipótese excepcional apenas possa ocorrer, frisa-se em áreas prioritárias identificadas pela União ou pelos Estados federados (o que já estava previsto no artigo 66, §6o, inciso III, do Código Florestal de 2012 - declarado constitucional), se esbarra, pós-decisão do Supremo Tribunal Federal no que seja considerado identidade ecológica.

Há de se ponderar que o termo identidade ecológica, por si só, possui um grande grau de imprecisão técnica que conturba a normatização do instrumento, além do mais não há uma definição legal sobre o que abarca esta expressão. De tal modo que este critério fomenta a insegurança jurídica e uma discricionariedade desparametrizada dos órgãos ambientais, seja para a compensação ambiental utilizando a Cota de Reserva Ambiental entre propriedades nos limites territoriais do Estado federal ou do Município, ou fora deles.

Rememorando que o artigo 44 do Código Florestal adverte que a Cota de Reserva Ambiental poderá ser instituída (sem olvidar dos outros critérios) em área com vegetação nativa, existente ou em processo de recuperação, o artigo 46 e incisos estabelece que cada cota corresponderá a um hectare: "I - de área com vegetação nativa primária ou com vegetação secundária em qualquer estágio de regeneração ou recomposição; II - de áreas de recomposição mediante reflorestamento com espécies nativas. "

Realmente é promissora a imposição ao órgão ambiental estadual competente de realizar a vistoria de campo (e não se pautar apenas em declarações feitas pelo proprietário) para analisar o estágio sucessional ou o tempo de recomposição ou regeneração da vegetação nativa. Sobretudo para coibir que a cota seja emitida no local em que a regeneração ou recomposição da área forem improváveis ou inviáveis (conforme o artigo 46, §§ $1^{\circ}$ e $2^{\circ}$ do Código Florestal). No entanto depreende-se uma sucessão de imprecisões técnicas que impactam diretamente o instrumento.

Isso porque é primordial estipular o que seja estágio mínimo de regeneração ou da recomposição da vegetação secundária capaz de ensejar cota. Deixar a cargo dos órgãos ambientais estaduais a avaliação dessas situações nas áreas ambientais do país, sem qualquer critério geral ou parâmetro legal, torna altamente discricionária a atuação deles.

A não existência de um padrão nacional sobre a definição de estágio mínimo de regeneração ou de recomposição da vegetação secundária, conturba não apenas a Cota de Reserva Ambiental, mas também a aplicação de outros dispositivos do Código Florestal, bem

\footnotetext{
31 Conforme o artigo 16 e incisos do Decreto no 8.253/2014, as áreas prioritárias são aquelas (a) definidas pelo Ministério do Meio Ambiente no Projeto de Conservação e Utilização Sustentável da Diversidade Biológica Brasileira (PROBIO), conforme o Decreto no 5.092, de 21 de maio de 2004; (b) as Unidades de Conservação de domínio público pendentes de regularização fundiária; (c) as áreas que abriguem espécies migratórias ou ameaçadas de extinção, conforme a lista oficial publicada pelos órgãos integrantes do SISNAMA; e (d) aquelas identificadas pelos Estados e Distrito Federal.

32 Código Florestal de 2012, "Art. 66, §7º. A definição de áreas prioritárias de que trata o §6o buscará favorecer, entre outros, a recuperação de bacias hidrográficas excessivamente desmatadas, a criação de corredores ecológicos, a conservação de grandes áreas protegidas e a conservação ou recuperação de ecossistemas ou espécies ameaçados.”
} 
como de diversas legislações esparsas e atos normativos expedidos pelos órgãos ambientais, que utilizam estas expressões.

No âmbito do bioma Mata Atlântica, o artigo $4^{\circ}$ da Lei no 11.428/2006 dispõe que "a definição de vegetação primária e de vegetação secundária nos estágios avançado, médio e inicial de regeneração do Bioma Mata Atlântica, nas hipóteses de vegetação nativa localizada, será de iniciativa do Conselho Nacional do Meio Ambiente". Frisa-se que o Decreto no 6.66o/20o8 regulamenta sobre a utilização e proteção nativa deste bioma.

Não obstante coexistirem aprimoramentos das definições emitidas pelo Conselho Nacional do Meio Ambiente (CONAMA), quando a particularidade da região assim impõe, o órgão federal estabelece na Resolução CONAMA no 10/1993 os parâmetros básicos para análise dos estágios de sucessão de Mata Atlântica.

A vegetação primária deve ser entendida como a "vegetação de máxima expressão local, com grande diversidade biológica, sendo os efeitos das ações antrópicas mínimos, a ponto de não afetar significativamente suas características originais de estrutura e de espécies". Por sua vez, a vegetação secundária ou em regeneração como a "vegetação resultante dos processos naturais de sucessão, após supressão total ou parcial da vegetação primária por ações antrópicas ou causas naturais, podendo ocorrer árvores remanescentes da vegetação primária" (artigo $2^{-}$, incisos I e II, da Resolução CONAMA no 10/1993). E os estágios de regeneração da vegetação secundária podem ser classificados em inicial, médio e avançado33.

Logo, os órgãos ambientais estaduais abrangidos pelo bioma Mata Atlântica deverão observar os critérios (gerais e específicos) estabelecidos pelo CONAMA, embora ainda não esteja claro o que se entende por estágio mínimo de regeneração.

No entanto, nos outros biomas não se vislumbrou leis nacionais ou mesmo Resoluções do CONAMA, que mencionem sobre a definição do estágio de regeneração da vegetação e acerca do que é vegetação primária e secundária. Nestes casos poderá se utilizar analogicamente o regramento do bioma Mata Atlântica, o qual, por óbvio, não está atento as especificidades dos outros grandes biomas nacionais, quais sejam: Cerrado, Amazônia Legal, Caatinga, Pampas e Pantanal.

Portanto, reforça-se que o melhor seria que o Código Florestal definisse ou ao menos estabelecesse critérios gerais acerca do que seja estágio mínimo de regeneração ou de recomposição, bem como do que seja vegetação primária ou secundária, a serem considerados pelos órgãos ambientais estaduais, ao invés de estender esta função (típica) ao órgão ambiental federal.

33 Resolução CONAMA no 10, de 1 de outubro de 1993: "Art. 3ํ. Os estágios de regeneração da vegetação secundária a que se refere o artigo 6o do Decreto no 75o/93, passam a ser assim definidos: I - Estágio Inicial: a) fisionomia herbáceo/arbustiva de porte baixo, com cobertura vegetal variando de fechada a aberta; b) espécies lenhosas com distribuição diamétrica de pequena amplitude; c) epífitas, se existentes, são representadas principalmente por líquenes, briófitas e pteridófitas, com baixa diversidade; d) trepadeiras, se presentes, são geralmente herbáceas; e) serapilheira, quando existente, forma uma camada fina pouco decomposta, contínua ou não; f) diversidade biológica variável com poucas espécies arbóreas ou arborescentes, podendo apresentar plântulas de espécies características de outros estágios; g) espécies pioneiras abundantes; h) ausência de subosque.

II - Estágio Médio: a) fisionomia arbórea e/ou arbustiva, predominando sobre a herbácea, podendo constituir estratos diferenciados; b) cobertura arbórea, variando de aberta a fechada, com a ocorrência eventual de indivíduos emergentes; c) distribuição diamétrica apresentando amplitude moderada, com predomínio de pequenos diâmetros; d) epífitas aparecendo com maior número de indivíduos e espécies em relação ao estágio inicial, sendo mais abundantes na floresta ombrófila; e) trepadeiras, quando presentes são predominantemente lenhosas; f) serapilheira presente, variando de espessura de acordo com as estações do ano e a localização; g) diversidade biológica significativa; $h$ ) subosque presente.

III - Estágio Avançado: a) fisionomia arbórea, dominante sobre as demais, formando um dossel fechado e relativamente uniforme no porte, podendo apresentar árvores emergentes; b) espécies emergentes, ocorrendo com diferentes graus de intensidade; c) copas superiores, horizontalmente amplas; d) distribuição diamétrica de grande amplitude; e) epífitas, presentes em grande número de espécies e com grande abundância, principalmente na floresta ombrófila; f) trepadeiras, geralmente lenhosas, sendo mais abundantes e ricas em espécies na floresta estacional; g) serapilheira abundante; h) diversidade biológica muito grande devido à complexidade estrutural; i) estratos herbáceo, arbustivo e um notadamente arbóreo; j) florestas neste estágio podem apresentar fisionomia semelhante à vegetação primária; l) subosque normalmente menos expressivo do que no estágio médio; $\mathrm{m}$ ) dependendo da formação florestal, pode haver espécies dominantes." 
Afinal, a falta de critérios técnicos claros favorece a discricionariedade arbitrária na regulamentação e avaliação pelos próprios órgãos ambientais e de futuras apreciações jurisdicionais no âmbito da cota (que ainda pode ser interestados), causando a insegurança jurídica.

E, embora o artigo 46 do Código Florestal não tenha sido objeto de apreciação jurisdicional, de forma reflexa entende-se que o seu teor foi confirmado ao ser declarado constitucional o artigo 44.

\subsection{O futuro da Cota De Reserva Ambiental no Brasil e a questão do retrocesso socioambiental}

Não há uma certeza de como a Cota de Reserva Ambiental irá afetar o espectro verde nativo do país, mas se prognostica a concentração estratégica de áreas ambientalmente protegidas, em extensões maiores, com a fiscalização do Poder Público e mais assiduamente dos particulares (em razão das contratações), havendo um estímulo a governança ambiental.

Corrobora com este raciocínio os dados a seguir sobre a extensão da cobertura de vegetação nativa no Brasil, elaborados por Britaldo Silveira Soares Filho, professor titular do departamento de cartografia, do Instituto de Geociências da Universidade Federal de Minas Gerais.

Sessenta e dois por cento do território nacional, ou seja, cerca de 530 milhões de hectares (Mha) são cobertos por vegetação nativa. Desse total, 40\% se encontra em áreas de conservação de domínio público ou em terras indígenas - sendo que $91 \%$ dessa fração se concentra apenas no bioma Amazônia - e os 60\% restantes em propriedades privadas ou terras públicas ainda sem designação. Números, portanto, que apontam para a necessidade de esforços de conservação em larga escala dessa vasta cobertura de vegetação nativa que se encontra dispersa em fragmentos de vários tamanhos através de uma miríade de propriedades privadas. (2013?, p. 3)

Assim, através de uma estratégia holística de gerenciamento ${ }^{34}$ integrado dos espaços ambientalmente protegidos, as normas e as políticas públicas podem ser (re)formuladas primando pelo equilíbrio entre as demandas ecológicas, econômicas e sociais, aliando as novas tendências protetivas e tecnológicas, sobretudo para manter as florestas em pé, como tenciona a Cota de Reserva Ambiental.

Urge esclarecer que a cota em si não extingue a obrigatoriedade de os proprietários rurais manterem Área de Reserva Legal, quiçá Área de Preservação Permanente ${ }^{35}$. Ademais, ela é uma das opções disponíveis no processo de regularização ambiental e que apenas poderá ser utilizada na compensação ambiental de degradações ocorridas até 22/07/2008 - ou seja, não poderá ser utilizada para presentes e futuras violações ambientais.

Por via reflexa as teses até aqui apresentadas, o argumento do princípio da vedação de retrocesso socioambiental estaria presente quando se compara a normatização da Cota de Reserva Ambiental no Código Florestal de 2012 com a da sua antecessora (revogado Código Florestal de 1965). Ao revés desse "retrocesso", na atual versão, a cota tem condicionantes

\footnotetext{
34 Urge diferenciar gerenciamento de gestão ambiental. O primeiro é um "sistema ou modalidade de administrar problemas e interesses relativos ao meio ambiente em escala operacional e no âmbito de assuntos específicos. A gestão ambiental, ao invés, se ocuparia da definição de objetivos e políticas, assim como da chamada governança, da implementação de medidas concretas em casos particulares, valendo-se dos métodos e meios propiciados pelo planejamento que se pratica tanto no setor público, como na iniciativa privada." (MILARÉ, 2015, p. 638)

35 Conceitua o Código Florestal de 2012, no artigo 3º, inciso II, "Área de Preservação Permanente - APP: área protegida, coberta ou não por vegetação nativa, com a função ambiental de preservar os recursos hídricos, a paisagem, a estabilidade geológica e a biodiversidade, facilitar o fluxo gênico de fauna e flora, proteger o solo e assegurar o bem-estar das populações humanas. ”
} 
próprias e delimitadas que a tornam um potencial instrumento de proteção ao meio ambiente, atingindo principalmente a regularização ambiental das áreas degradas até o dia 22/08/2008.

Inicialmente urge compreender que o princípio da vedação de retrocesso socioambiental decorre de uma construção histórica de reconhecimento de direitos fundamentais na seara ambiental e social, que no Estado de Direito (Ambiental ${ }^{36}$ ) devem ser mantidos ou aprimorados. Por conseguinte, o princípio funciona como um coibidor de tentativas regressivas aos direitos fundamentais, impulsionadas por interesses políticos ou jurídicos corruptivos. Sobre o princípio em epígrafe, mister colacionar as ponderações de Sarlet e Fensterseifer:

Em linhas gerais, portanto, é possível afirmar que a garantia da proibição de retrocesso tem por escopo preservar o bloco normativo - constitucional e infraconstitucional já construído e consolidado no ordenamento jurídico, especialmente naquilo em que objetiva assegurar a fruição dos direitos fundamentais, impedindo ou assegurando o controle de atos que venham a provocar a supressão ou restrição dos níveis de efetividade vigentes dos direitos fundamentais. (2010, p. 10)

A atuação do Poder Público deve estar em consonância com os pressupostos constitucionais e legais aliados ao princípio da vedação de retrocesso ecológico (que tem estreita relação com a proteção da dignidade humana). Sendo conclusivo que o Poder Legislativo não deve escorar-se indevidamente no princípio democrático para utilizar de maneira arbitrária a discricionariedade que lhe é peculiar na elaboração de normas.

Adverte Prieur (2012, p. 18) que em matéria ambiental, o retrocesso é inimaginável, "[n]ão se pode considerar uma lei que, brutalmente, revogue normas antipoluição ou normas sobre a proteção da natureza; ou, ainda, que suprima, sem justificativa, áreas ambientalmente protegidas".

É importante compreender que o princípio da vedação de retrocesso não estanca a dinamicidade própria da sociedade, ou seja, ele leva em consideração as constantes transformações sociais, políticas, jurídicas, ambientais, econômicos e avanços tecnológicos. Por outro lado, impõe que no processo de atualização (ou melhor, correspondência) do ordenamento jurídico com a atual conjuntura social, este seja feito com critérios e respeito a todo o conjunto de direitos e obrigações basilares consolidados. Neste sentido, explica Prieur:

\begin{abstract}
A não regressão vai, assim, se situar num cursor entre a maior despoluição possível - que evoluirá no tempo, graças aos progressos científicos e tecnológicos - e o nível mínimo de proteção ambiental, que também evolui constantemente. O recuo hoje não seria o mesmo recuo de ontem, como se pode notar das palavras de Naim Gesbert (2011, p. 28), para quem a não regressão permite uma adaptação "evolutiva, em espiral ascendente", do Direito Ambiental. (2012, p. 24-25)
\end{abstract}

O limite material ao princípio da vedação de retrocesso é a preservação do mínimo existencial socioambiental, que é o núcleo essencial dos direitos fundamentais que abrange "o conjunto de prestações materiais que asseguram a cada indivíduo uma vida com dignidade, no sentido de uma vida saudável, ou seja, de uma vida que corresponda a padrões qualitativos mínimos. " (SARLET; FENSTERSEIFER, 2010, p. 18)

Não obstante haver uma flexibilização na regulamentação da Cota de Reserva Ambiental no Códex florestal vigente e que o instrumento precisa de adequações pós-decisão do Supremo

36 Carvalho (2017, p. 113-114) explica que "o Estado democrático ambiental tem por escopo a formação de um 'Estado de justiça ambiental', proibindo-se iniquidade e qualquer espécie de discriminação, tidas através de quaisquer decisões, seleções, práticas administrativas ou ações materiais que digam respeito à tutela ambiental ou à transformação do território e que onerem de forma injusta determinados grupos, comunidades, minorias, indivíduos, em vista de sua raça, situação econômica ou localização geográfica”. Ademais, urge destacar que o "Estado Ambiental terá de ser, por evidente, um Estado de Direito, desprezando-se qualquer autoritarismo ou fundamentalismo ambiental”. (CARVALHO, 2017, p. 114) Ou seja, na análise de causas ambientais, o autor deve manter a racionalidade jurídica em consonância com a realidade, mas sem se subverter ao ativismo ambiental ou econômico. 
Tribunal Federal, o núcleo essencial de proteção e manutenção do meio ambiente ecológico via cotização de áreas verdes nativas ainda está preservado. Logo não deve prosperar a tese de que neste caso há violação ao princípio da vedação de retrocesso socioambiental.

Outrossim ao analisar a instituição da Cota de Reserva Ambiental no Brasil, o Instituto de Pesquisa Ambiental da Amazônia (IPAM) apontou alguns benefícios ambientais com essa estratégia, tais como:

Com a instituição das CRAs, se preserva o que já existe, com a vantagem de que a área sobre a qual foi instituída, além de ficar protegida, ainda recebe um incentivo financeiro para a sua conservação. Assim, em vez de um proprietário recuperar uma floresta mais pobre em biodiversidade e serviços ecossistêmicos enquanto outro desmata uma floresta mais rica, mantém-se em pé a floresta rica e diversa. Além disso, a instituição das CRAs pode ajudar a financiar a recuperação da vegetação nativa em áreas degradadas que não tenham boas possibilidades produtivas. (2015, p. 9)

Destarte, sem olvidar dos outros instrumentos e medidas para a preservação das florestas nacionais e que caberá ao órgão ambiental competente avaliar qual a melhor estratégia a ser utilizada, a Cota de Reserva Ambiental destaca-se por ser um novo método (teoricamente promissor) de reconhecimento àqueles que mantém áreas verdes superavitárias em suas propriedades e de gerenciamento florestal.

Outro ponto de merece ser destacado é a importância da fixação de uma data para a utilização da Cota de Reserva Ambiental, pois faz com que o instrumento seja exequível, transparente e criterioso.

O artigo 66 do Código Florestal de 2012 estabelece que os proprietários de imóveis rurais poderão utilizar a compensação ambiental, via Cota de Reserva Ambiental, para regularizar as áreas de vegetação natural devastadas até o dia 22/07/2008. Esta data se refere à promulgação do Decreto presidencial no $6.514^{37}$.

Não obstante o Supremo Tribunal Federal ter se posicionado pela constitucionalidade deste artigo, insiste-se que o mais acertado teria sido a utilização da Medida Provisória n⿳o 2.166-67/2001 ${ }^{38}$, como marco temporal.

Primeiro porque, como bem assevera Carvalho (2017, p. 46), os atos normativos no Brasil possuem hierarquia funcional, balizada no artigo 59 da Constituição Federal de 1988, que sem olvidar da supremacia da Constituição, dispõe a seguinte ordem decrescente: emendas à Constituição, leis complementares, leis ordinárias, leis delegadas, medidas provisórias, decretos legislativos e resoluções.

A Medida Provisória é um ato normativo com força de lei39, que poderá ser expedida em caso de relevância e urgência pelo Presidente da República, a qual deverá ser submetida imediatamente ao Congresso Nacional (artigo 62 da Constituição Federal de 1988). Por outro lado, o Decreto presidencial é um ato administrativo formal, que deve vir a complementar ou

37 Dispõe sobre as infrações e sanções administrativas ao meio ambiente, o processo administrativo federal para apuração destas infrações, dentre outras providências.

38 Expedida pelo Chefe maior do Poder Executivo nacional, esse decreto foi responsável por ter modificado o revogado Código Florestal, estabelecendo que deveria ser mantido a título de Área de Reserva Legal o percentual mínimo de $80 \%$ na propriedade rural situada no bioma Amazônia Legal; 35\% se estivesse no Cerrado localizado na Amazônia Legal, sendo no mínimo $20 \%$ na propriedade e $15 \%$ na forma de compensação ambiental em outra área localizada na mesma microbacia hidrográfica; $20 \%$ se estivesse em área de florestal, em outras formas de vegetação nativa ou em Campos Gerais.

39 O Supremo Tribunal Federal pacificou o seguinte entendimento: "O que justifica a edição dessa espécie normativa, com força de lei, em nosso direito constitucional, é a existência de um estado de necessidade, que impõe ao poder público a adoção imediata de providências, de caráter legislativo, inalcançáveis segundo as regras ordinárias de legiferação, em face do próprio periculum in mora que fatalmente decorreria do atraso na concretização da prestação legislativa. (...) É inquestionável que as medidas provisórias traduzem, no plano da organização do Estado e na esfera das relações institucionais entre os Poderes Executivo e Legislativo, um instrumento de uso excepcional. A emanação desses atos, pelo presidente da República, configura momentânea derrogação ao princípio constitucional da separação dos Poderes. [ADI 221 MC, rel. min. Moreira Alves, voto do min. Celso de Mello, j. 29-3-1990, P, DJ de 22-10-1993.]." 
regulamentar uma lei, e não suprimir a competência material ${ }^{40}$ de um ato legislativo. Logo, a Medida Provisória possui status hierárquico normativo superior ao do Decreto.

Segundo porque, este novo marco temporal iria acrescer em mais de sete anos de degradação ambiental causados no interior das propriedades rurais do país absorvidos pelo Decreto presidencial no $6.514 / 2008$, e que, por conseguinte, deveriam ser regularizados pelos métodos comuns.

O retrocesso socioambiental quanto à possibilidade de usar a Cota de Reserva Ambiental para compensar áreas ambientais deterioradas até 22/07/2008 e a desobrigação das pequenas propriedades rurais não são vícios constitucionais do instrumento em si. Mas sim de dispositivos conexos, que também inferem em outros institutos do Código Florestal, os quais mesmo pós-decisão do Supremo Tribunal Federal, ainda conturbam a real efetivação do instrumento e a consubstanciação de seus impactos positivos.

\section{CONSIDERAÇÕES FINAIS}

A sistemática do direito promocional aliada ao princípio do protetor-recebedor exteriorizado no Sistema de Pagamento por Serviços Ambientais, possibilita ao Poder Público uma nova concepção para a gestão ambiental, com a promoção e bonificação pelas ações positivas (em detrimento das puramente sancionatórias) para a efetiva proteção e ampliação do direito fundamental ao meio ambiente ecologicamente equilibrado.

Raciocínio que intensifica o mandamento constitucional de corresponsabilidade à defesa do meio ambiente natural, evidenciado nas áreas rurais do país, que prescinde de um entrelaçamento maior do Poder Público com os proprietários rurais (haja vista que possui uma parcela resistente ao ecologismo), viabilizando mais interações particulares - ainda que sob a verniz econômico - em prol da coletividade (intergeracional).

Ante o exposto, é possível deduzir que a Cota de Reserva Ambiental, como título de crédito (nominativo), (a) é uma alternativa factível para que os imóveis rurais deficitários ambientalmente, sejam adequados aos ditames constitucionais e legais de proteção da natureza; (b) apresenta um novo nicho mercadológico relacionado à proteção ambiental; (c) promove o reconhecimento e o estímulo econômico aos próprios proprietários rurais para manterem áreas ambientais nativas, até mesmo, em percentuais superavitários.

Não obstante as intenções com a implantação da Cota de Reserva Ambiental serem positivas para a manutenção e ampliação de áreas verdes ecológicas, bem como para auxiliar o proprietário de imóvel rural deficitário ambientalmente à regularizá-lo, inconteste que o instrumento possui alguns direcionamentos do agrobussiness.

E não há como não se concluir que a avaliação técnica-jurídica do Supremo Tribunal Federal, em muitos pontos, tornou a regulamentação e a aplicação deste instrumento ainda mais conturbada. Por isso é preciso analisá-lo e o operacionar com cautela, tendo como base a engenharia constitucional (regras e princípios) de proteção ambiental.

Com a utilização da Cota de Reserva Ambiental, em sua atual normatização, é imprescindível a maturação técnica, jurídica e política do instrumento, para que efetivamente seja uma boa estratégia a ser usufruída pela sociedade do século XXI, levando-se em

40 "Em matéria ambiental, não raras as vezes, há um processo de verdadeira ampliação das restrições a direitos subjetivos por meio de instrumentos normativos infralegais, tais como resoluções, portarias ou instruções normativas. Como é sabido, os decretos legislativos têm a função exclusiva de regulamentar determinada norma legal, tendo, portanto, a 'estrita finalidade de produzir as disposições operacionais uniformizadoras necessárias à execução de lei cuja aplicação demande atuação da Administração Pública. ' De tal maneira, os regulamentos [e as demais espécies infralegais expedidas, sobretudo, pelo Poder Executivo] não podem transformar ou ampliar o caráter restritivo aos direitos subjetivos, sob pena de violação ao Princípio da Legalidade, como elemento estruturante do Estado de Direito." (CARVALHO, 2017, p. 46-47). 
consideração a prevalência do princípio do protetor-recebedor, em razão da pouca eficácia da simples punição do poluidor. O desenvolvimento sustentável, neste sentido, demanda um repensar quanto aos clássicos mecanismos e ideologias de tutela dos bens ambientais. A futura geração depende de propostas mais efetivas desenvolvidas no presente, dentre elas, a utilização da Cota de Reserva Ambiental sob à égide de uma preservação e recuperação do meio ambiente inteligente e socioeconomicamente viável.

\section{REFERÊNCIAS}

ALTMANN, Alexandre. Princípio do preservador-recebedor: contribuições para a consolidação de um novo princípio de direito ambiental a partir do sistema de pagamento por serviços ambientais. p. 125 - 161. In: Princípios do Direito Ambiental: Atualidades. v. 1. SILVEIRA, Clóvis Eduardo Malinverni da (Org.). Caxias do Sul: EDUCS, 2012. Disponível em: <http:// www1.tce.rs.gov.br/portal/page/portal/tcers/institucional/esgc/biblioteca_eletronica/livros/ principios_direito_ambiental_EDUCS_ebooks.pdf >. Acesso em: o8 abr. 2018.

BRASIL. Constituição da República Federativa, 1988. Disponível em: <http://www.planalto. gov.br/ccivil_03/constituicao/constituicao.htm>. Acesso em: o1o fev. 2017.

Lei no 12.651, de 25 de maio de 2012. Dispõe sobre a proteção da vegetação nativa; altera as Leis nos 6.938, de 31 de agosto de 1981, 9.393, de 19 de dezembro de 1996, e 11.428, de 22 de dezembro de 2006 ; revoga as Leis $n^{\text {os }} 4.771$, de 15 de setembro de 1965 , e 7.754, de 14 de abril de 1989, e a Medida Provisória no 2.166-67, de 24 de agosto de 2001; e dá outras providências. Disponível em: <http://www.planalto.gov.br/ccivil_03/_ato2011-2014/2012/lei/ l12651.htm>. Acesso em: o8 abr. 2018.

Lei no 4.771, de 15 de setembro de 1965. Institui o novo Código Florestal. Disponível em: <http://www.planalto.gov.br/ccivil_03/leis/l4771.htm>. Acesso em: o9 abr. 2018.

Lei no 6.938, de 31 de agosto de 1981. Dispõe sobre a Política Nacional do Meio Ambiente, seus fins e mecanismos de formulação e aplicação, e dá outras providências. Disponível em: <http://www.planalto.gov.br/ccivil_o3/leis/l6938.htm>. Acesso em: o8 abr. 2018.

Superior Tribunal de Justiça (STJ). Agravo em Recurso Especial 1149867 MG 2017/0197092-6. Relator: Ministra Assusete Magalhães. Data da Publicação: DJ 24/10/2017. Disponível em: <http://www.stj.jus.br/SCON/ decisoes/toc.jsp?livre=im\%F3vel+rural+com+\%E1rea+de+at\%E9+o4+\%28quatr $\mathrm{o} \% 29+\mathrm{m} \% \mathrm{~F}_{3}$ dulos+fiscais+est $\% \mathrm{E}_{1}+$ desonerado+de+constitui $\% \mathrm{E}_{7} \% \mathrm{E}_{3} \mathrm{O}+\mathrm{da}+\mathrm{averba} \mathrm{E}_{7}$ $\% \mathrm{E}_{30}+\mathrm{da}+$ reserva+legal\&\&b=DTXT\&thesaurus=JURIDICO\&p=true>. Acesso em: 29 maio 2018.

Supremo Tribunal Federal (STF). Ação Direta de Inconstitucionalidade no 4.901 - DF. Relator: Ministro Luiz Fux. Data de Protocolo: 13 jan. 2013. Data da Autuação: 21 jan. 2013. Disponível em: <http://www.stf.jus.br/portal/processo/verProcessoAndamento. asp?incidente $=4355097>$. Acesso em: 10 abr. 2018. 
Supremo Tribunal Federal. Ação Direta de Inconstitucionalidade no 4.937 - DF. Relator: Ministro Luiz Fux. Data de Protocolo: 04 abr. 2013. Data da Autuação: o4 abr. 2013. Disponível em: <http://www.stf.jus.br/portal/processo/verProcessoAndamento. asp?incidente $=4388129>$. Acesso em: 10 abr. 2018.

CARVALHO, Delton Winter de. Estado de Direito Ambiental. In: Gestão Jurídica Ambiental. São Paulo: Revista dos Tribunais, 2017.

CONSELHO NACIONAL DO MEIO AMBIENTE (CONAMA). Resolução no $\mathbf{1 0}$, de $\mathbf{1}$ de outubro de 1993. Disponível em: <http://www.mma.gov.br/port/conama/legiabre.cfm?codlegi=135>. Acesso em: o9 abr. 2018.

FRENTE PARLAMENTAR DA AGROPECUÁRIA (FPM). Integrantes. 2018?. Brasília. Disponível em: <http://fpagropecuaria.org.br/integrantes/todos-os-integrantes/>. Acesso em: 18 maio 2018.

INSTITUTO DE PESQUISA AMBIENTAL DA AMAZÔNIA (IPAM). Cotas de Reserva Ambiental (CRA) para a conservação e o desenvolvimento sustentável: informações básicas para tomadores de decisão nos Estados/Elaboração. AZEVEDO, Andrea A.; STABILE, Marcelo C. C.; REIS, Tiago N. P. (Coord.). Brasília: IPAM, 2015.

INSTITUTO NACIONAL DE COLONIZAÇÃO E REFORMA AGRÁRIA (INCRA). Consulta de Imóveis Rurais-Brasil. Brasília, 2016. Disponível em: <http://www.incra.gov.br/sites/default/ files/uploads/estrutura-fundiaria/estat-sticas-de-im-veis-rurais-/brasil_cadastro_imoveis_ rurais_geral_pub_e_priv.pdf $>$. Acesso em: 18 maio 2018.

JURAS, Ilidia da Ascenção Garrido Martins; GANEM, Roseli Senna. Código Florestal: Tabela comparativa dos textos da Câmara, do Senado e Redação final. Elaborado pela Consultoria Legislativa. Brasília: Biblioteca Digital da Câmara dos Deputados, abr. de 2012. Disponível em: <http://bd.camara.leg.br/bd/handle/bdcamara/9048>. Acesso em: 10 abr. 2018.

LEHFELD, Lucas de Souza; CARVALHO, Nathan Castelo Branco de; BALBIM, Leonardo Nassif. Código Florestal comentado e anotado: artigo por artigo. 3. ed. São Paulo: Método, 2015.

MACHADO, Paulo Affonso Leme. Direito Ambiental Brasileiro.21. ed. São Paulo: Malheiros, 2013.

MANGUEIRA, Carlos Otaviano de M. Função Social da Propriedade e Proteção ao Meio Ambiente: Notas sobre os Espaços Protegidos nos Imóveis Rurais. Revista de Informação Legislativa, Brasília, Subscretaria de Edições Técnicas do Senado Federal, ano 37, n. 146, 2000.

MENEZES, Gustavo Quintanilha Telles de. As partes na Ação Direta de Inconstitucionalidade e na Ação Direta de Constitucionalidade. In: Normatividade Jurídica: Curso de Constitucional. Série Aperfeiçoamento de Magistrados 11. Escola da Magistratura do Estado do Rio de Janeiro - EMERJ, Rio de Janeiro, p. 78-91, mai. 2012. Disponível em:<http://www.emerj.tjrj.jus.br/ serieaperfeicoamentodemagistrados/paginas/series/11/normatividadejuridica_78.pdf $>$. Acesso em: 10 abr. 2018. 
MILARÉ, Édis. Direito do Ambiente. 10. ed. São Paulo: Revista dos Tribunais, 2015.

PRIEUR, Michel. Princípio da proibição de retrocesso ambiental. Tradução de José Antônio Tietzmann e Silva. In: O princípio da proibição de retrocesso ambiental. Brasília-DF: Senado Federal; Comissão de Meio Ambiente, Defesa do Consumidor e Fiscalização e Controle (CMA), 2012. p. 11-54. Disponível em: <http://www2.senado.leg.br/bdsf/item/id/242559>. Acesso em: 11 abr. 2018.

RAJÃO, Raoni. Cotas de reserva ambiental (CRA): viabilidade econômica e potencial do mercado no Brasil. In: RAJÃO, Raoni; SOARES FILHO, Britaldo Silveira (Coord.). 1. ed. Belo Horizonte: Editora IGC/UFMG, 2015. Disponível em: <http://csr.ufmg.br/cra/Rajao_Soares_15_ CRA\%2ono\%2oBrasil_hires.pdf>. Acesso em: o9 abr. 2018.

REYDON, Batiann Philip. A regulação institucional da propriedade da terra no Brasil: uma necessidade urgente. In: Dimensões do agronegócio brasileiro: políticas, instituições e perspectivas. RAMOS, Pedro (Org.). Brasília: Nead Estudos, 2007. p. 226-262. Disponível em: <http://www.cairu.br/biblioteca/arquivos/Agronegocios/Dimensoes_do_agronegocio_ brasileiro.pdf>. Acesso em: 10 abr. 2018.

SARLET, Ingo Wolfgang; FENSTERSEIFER, Tiago. Notas sobre os deveres de proteção do Estado e a garantia da proibição de retrocesso em matéria (socio)ambiental. 2010. Disponível em: <http://www.planetaverde.org/biblioteca-virtual/artigos-juridicos/notassobre-os-deveres-de-protecao-do-estado-e-a-garantia-da-proibicao-de-retrocesso-emmateria-socioambiental>. Acesso em: 11 abr. 2018.

SOARES FILHO, Britaldo Silveira. Impacto da revisão do Código Florestal: como viabilizar o grande desafio adiante? Brasil: Secretaria de Assuntos Estratégicos, 2013?. Disponível em: $<$ https://www.socioambiental.org/sites/blog.socioambiental.org/files/nsa/arquivos/artigocodigo-florestal_britaldo_soares_sae_2013pdf.pdf>. Acesso em: 02 jun. 2017.

SUPREMO TRIBUNAL FEDERAL (STF). A Constituição e o Supremo: Artigo 62. Brasília: 2017. Disponível em: <http://www.stf.jus.br/portal/constituicao/artigoBd.asp?item=809>. Acesso em: 11 abr. 2018. 